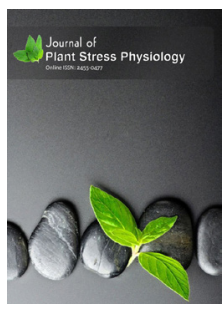

ISSN: $2455^{-0477}$

\title{
Growth performance and nutritional quality of selected vegetables in response to organic and inorganic fertilizers under low and high irradiance
}

\author{
L. T. Olaokiki and S. A. Adejumo* \\ Department of Crop Protection and Environmental Biology, Faculty of Agriculture, University of Ibadan, Ibadan, Nigeria
}

Received: September 21, 2020

Revised: February 27, 2021

Accepted: March 13, 2021

Published: April 01, 2021

*Corresponding Author:

S. A. Adejumo

Email: nikade_05@yahoo.com

\begin{abstract}
Vegetables form major part of human dietary/nutritional needs. It provides the necessary vitamins and minerals as well as antioxidants to boost immunity. Different vegetables however have different benefits and require different growing conditions. This study investigated the effect of two growing conditions (Screen-house and open field) and soil amendments; Mexican sunflower compost (MSC; applied at 0, 5, $10 \mathrm{t} / \mathrm{ha}$ ) and NPK 15:15:15 (applied at 0, 50 and $100 \mathrm{~kg}$ $\mathrm{N} / \mathrm{ha}$ ) on the growth performance, yield, and nutritional quality of five selected vegetables (Amaranthus cruentus, Celosia. argentea, Solanum macrocarpon, Solanum nigrum and Solanum incanum). Each treatment was replicated three times and experiment arranged in completely randomized design, Compost was applied a week before seed sowing and NPK applied two weeks after sowing. Data were collected on growth, food quality and yield parameters as well as chlorophyll and micronutrient contents of each vegetable. At harvesting, proximate and nutrient analyses were carried out following standard procedures. Data were analysed using analysis of variance and means separated using Duncan Multiple Range Test (DMRT). The results showed that vegetables grown in the screen-house generally performed better than the open field in terms of leaf area and chlorophyll content. The response however varied based on the vegetable and the soil amendments. Solanum species, performed better than Amaranthus under screen-house than open field. Chlorophyll in the leaf responded positively to NPK fertiliser under screen-house conditions while growth parameters such as plant height, stem girth, number of leaves under screen-house and field conditions varied depending on the vegetables. The number of leaves and leaf area increased with soil amendments. Moisture, crude protein and ash contents were reduced under open field compared to screen-house. The zinc and iron contents of the vegetable leaves showed that addition of compost was superior to NPK and screen-house better than open field. It can be concluded that vegetables grown in the screen-house performed better in their respective growth parameters than vegetables grown under the open field.
\end{abstract}

KEYWORDS: Light intensity; Organic amendments; Vegetables; Secondary metabolites; Nutrients and Vitamins

\section{INTRODUCTION}

Vegetables are the cheapest, available sources of important nutrients supply in daily diets (Akinfolarin \& Gbarakoro, 2016). They provide the necessary vitamins and minerals as well as antioxidants. The antioxidants present in vegetables have been reported to prevent oxidative damage caused by reactive oxygen species which are generated in response to different stress factors (Halliwell \& Gutteridge, 1989). The antioxidants also help in boosting immunity and induce resistance against sickness and diseases. They are also good sources of limiting micronutrients; iron and zinc thereby eliminating hidden hunger (Kennedy et al., 2003). They contain carbohydrates, carotene, protein, vitamins, other essential mineral elements (Barminas et al., 1998). The edible part(s) of a vegetable could be stems, leaf, fruits/pods and stalk (celery) which can be eaten raw or cooked in a mixed dish as an appetizer or in a salad (Dhellot et al., 2006). In addition, they serve as important source of income for farmers. Green leafy vegetables are also used in the diet of nursing mothers to aid the contraction of the uterus (Emebu \& Anyika, 2011). Diets with high vegetable contents have been reported to have an ameliorative effect on hypertensive patients (Jerzykiewicz, 2007; Martirosyan et al., 2007). 
Different vegetables however, have different benefits. For instance, the Solanum species in the family Solanaceae (night shadow plants) are reported to have high amount of secondary metabolites which are naturally produced as a defense against herbivores (Roberts \& Wink, 1998). Similarly, Celosia vegetables, according to Asian Vegetable Research \& Development Center (AVRDC), also have high antioxidant contents that bind free radicals in the bloodstream and render them harmless. Principal antioxidants in Celosia include carotenoid (beta-carotene) and vitamins C and E (Sato \& Engle, 2002). Amaranthus vegetables are endowed with nutrients that are highly beneficial for reproductive health in both men and women. Research indicates that calcium that is present in amaranths improves the ability of sperms to swim while calcium deficiency impairs that same ability (Chinoy et al., 1983). Furthermore, vegetables influence the $\mathrm{pH}$ of the human body. Calcium in amaranth is said to help the body to achieve proper $\mathrm{pH}$ setting suitable for fertility and general reproductive function. Amaranth also has vitamin B9 or folate which is a major fertility booster. Folate deficiency is associated with anaemia and falling pregnancy and men's fertility is also positively influenced by foods rich in folate (Natural News, 2009).

Many vegetables are being cultivated by farmers while some still grow naturally in the wild. A. cruentus, C. argentea, A. spinosus S. macrocarpon, S. nigrum and S. incanum are produced by vegetable growers (Assogba-Komlan et al., 2007). S. macrocarpon is eaten in many countries of West Africa such as Togo, Ivory Coast and Nigeria (Sodipo et al., 2012). It is found everywhere in non-arid hot zones in Africa and is an important vegetable because of its leaves and fruits (Schippers, 2000). Amaranth originated in America and is one of the oldest food crops in the world. The genus Amaranth consists of nearly 60 species, several of which are cultivated as leafy vegetables, grains or ornamental plants, while others are weeds. Grain amaranth species are important in different parts of the world. A. cruentus is one of the most important annual leafy vegetables in the tropics and it has a short growing period of four to six weeks (Makinde, 2007). It thrives well on soils with high organic matter. S. nigrum among the Black nightshade family is also found in many places.

Vegetable production, though, important for animal and human survival, but, good understanding of their climatic and nutrient requirements would help to improve their productivity. Meanwhile, crop production is continuously confronted with unfavorable climatic conditions and the prevailing environmental factors are the key determinants for agricultural productivity and sustainability (Ferdous et al., 2011). The environmental factors are grouped into biotic and abiotic factors. Among the abiotic factors, light intensity, water and soil nutrients are very important factors that affect the vegetative and reproductive developments of vegetables (Xiao et al., 2000). For instance, light intensity and duration control the plantwater relationships and influences leaf growth, photosynthetic rates, pollination and vegetable yield. Plants are dependent on solar radiation and water to produce food, complete their life cycle and for healthy growth and development but, excessive sunshine have negative effects on crops and causes temperature stress (Smestad, 2014).
Similarly, to achieve better growth and high yield, vegetables must be supplied with adequate nutrients through the use of fertilisers which could be organic or inorganic. The use of organic fertiliser is however preferred to inorganic fertilisers due to environmental and health implications apart from its availability and cost benefits ratio. This research work was carried out to determine the morphological, physiological and yield responses of the selected vegetables to Mexican sunflower compost and NPK fertiliser under Screen-house (low irradiance) and open field (high irradiance) conditions and to evaluate the nutritional compositions of each vegetable in response to fertiliser application and growing conditions.

\section{METHODOLOGY}

\section{Soil Pre-treatment and Experimental Set-up}

The experiment consisted of two trials (main and residual plantings). Top soil used for the experiment was collected at the depth of $0-15 \mathrm{~cm}$ from the crop garden, air-dried, mixed thoroughly and sieved with $2 \mathrm{~mm}$ mesh before distributing into $5 \mathrm{~kg}$ experimental pots and arranged inside the screen house and on the open field. The average relative humidity, temperature, and light intensity for the screen-house were $79 \%, 33^{\circ} \mathrm{C}$ and 710 lux, respectively, while that of the open-field were $63 \%$, $39.6^{\circ} \mathrm{C}$ and 890.7 lux, respectively for the experimental period.

The treatments used were: Mexican sunflower compost and NPK fertiliser (15:15:15). Compost was applied at 0, 5 and $10 \mathrm{tt} / \mathrm{ha}$ and NPK at 0, 50 and $100 \mathrm{~kg} \mathrm{~N} / \mathrm{ha}$. The experimental design was Completely Randomized Design (CRD) in a factorial arrangement with three replicates. Compost was added to the soils receiving compost treatments at different rates, mixed thoroughly, watered and left for two weeks before the vegetable seeds were sown. The seeds of A. cruentus, C. argentea, A. spinosus S. macrocarpon, S. nigrum and S. incanum were were sown directly into the pots using broadcast method. Thinning was done two weeks after sowing to 2 plants per pot and watering was done regularly. NPK fertiliser was added two weeks after sowing. Data were collected on the growth, chlorophyll and yield parameters. Data collected on growth parameters include: plant height, leaf area and number of leaves. Leaf area $\left(\mathrm{cm}^{2}\right)$ was determined by measuring the leaf length and breadth of each vegetable using measuring tape. A. cruentus, and A. spinosus leaf areas were determined by multiplying L X B with 0.64 (Kolawole \& Sarah, 2009). C. argentea had calibration factor of 0.75 according to Agbogidi et al. (2005). S. macrocarpon, S. nigrum, S. incanum according to Flavio and Marcos (2003) had calibration factors: Length $\times$ breadth $\times 0.89$. Chlorophyll content was determined forthnightly using a hand-held SPAD-502 meter. At 8 weeks after sowing, the vegetables were gently uprooted from each pot. The roots were rinsed to wash the adhering soils back into the pots for the residual planting. They were partitioned into shoot and root, properly tagged for easy identification and carried to the laboratory. In the laboratory, they were weighed to determine the fresh weights using Metler sensitive weighing scale. They were then enveloped and labelled properly before oven drying for 72 hrs at $60{ }^{\circ} \mathrm{C}$ and weighed again to determine their dry weights. 
Before oven drying, leaf samples were taken for the determination of the moisture content. Samples for proximate analysis were taken from the treatments that performed well with regards to growth and yield parameters. One (1) gram each was taken from each vegetable and oven dried at $105^{\circ} \mathrm{C}$ for two hours until a constant weight was achieved. After drying, the moisture content was computed on wet basis: Weight of the sample before dryingWeight of the sample after drying/Weight of the sample $\times 100$.

After oven drying, for the determination of ash content, lg each of the ground vegetable samples was ashed in a Gallenkamp Muffle Furnace, FR 612 model, at a temperature of $550^{\circ} \mathrm{C}$ for 4 hours. Crucibles were first weighed before ashing and $\lg$ of the samples was weighed into each crucible and arranged into the furnace. After cooling, the ash was weighed again together with the crucibles and percent ash was calculated for each sample as: $\mathrm{WC}+\mathrm{SB}-\mathrm{WC}+\mathrm{SA} / \mathrm{WC}+\mathrm{SA} \times 100$. Where, $\mathrm{WC}=$ Weight of the crucible, $\mathrm{SB}=$ Weight of the sample before ashing and $\mathrm{SA}=$ Weight of the sample after ashing. Zinc and Iron were then determined in the ash following the procedure described by Ogundiran, (2007) using dry ashing method.

\section{RESULTS}

\section{Effects of Compost and NPK on the Growth Parameters of the Vegetables Under the Screen-house and Field Conditions.}

Generally, there was an increase in all the growth parameters as the week progressed. The response under screen-house and open field however varied based on the type of vegetables and the fertiliser application. However, for Amaranthus and Celosia species, some growth parameters were better under open field than screen house. On the number of leaves, A. cruentus in the screen-house was not different from those in the open field. At 2WAS control plant had the highest number of leaves and the trend continued till 6WAS. Under open field, addition of soil amendments enhanced leaf formation and at 6 WAS, the number of leaves of treated plants were more compared to control. C. argentea behaved differently. The number of leaves at 6WAS showed that in the screen-house, soil amendment with NPK at $100 \mathrm{kgN} /$ ha gave the highest number of leaves. Meanwhile, under the open field conditions, the highest number of leaves was recorded in plants grown in the soil amended with MSC at $10 \mathrm{t} /$ ha but not different from control. Compared to other vegetables, Solanum varieties (S. macrocarpon, S. incanum and $S$. nigrum) responded better in the soils treated with soil amendments both in the screen-house and under the open-field. S. macrocarpon especially had the highest number of leaves across all the treatments, followed by S. nigrum, and S. incanum. There was significant difference in the number of leaves of the Solanum varieties grown under screen-house and openfield. They also responded well to MSC than NPK at 6WAP (Table 1). For the plant height, A. cruentus performed better in the open field than screen-house and fertiliser application had no significant effect on plant height under the two conditions compared to control. C. argentea responded the same way as A. cruentus and the plant height was more on the field than screen-house at 2, 4 and 6 WAS tallest plant was produced in
MSC ( 5 t/ha) treatment under the open field at 4 and 6 WAS. Plant height was generally enhanced in the Solanum varieties grown in the screen-house compared to open field. At the end of 4 and 6 WAS, especially in the screen-house, S. incanum treated with $50 \mathrm{Kg} \mathrm{N} / \mathrm{ha}$ had the tallest plant while control gave the tallest plants under the open field. S. nigrum performed better in soil treated with $10 \mathrm{t} / \mathrm{ha}$ MSC under both conditions at 4 and 6 WAS. S. macrocarpon also had the tallest plants in $10 \mathrm{t} /$ ha MSC treatment in the screen-house and open field except at $6 \mathrm{WAS}$ in the open field when $100 \mathrm{Kg} \mathrm{N} /$ ha gave the tallest plant (Table 2). However, with regards to stem girth, A. cruentus responded well under screen-house conditions than open field. Application of compost enhanced stem girth in the screen-house and NPK at $50 \mathrm{kgN} /$ ha gave wide stem girths at $6 \mathrm{WAP}$ in the open field. The stem girth of C. argentea was not significantly different under both conditions at $6 \mathrm{WAS}$ and in response to the fertilizer application compared to control. Solanum vegetables also responded better under screen-house compared to open field and the stem girth was wider in the screen-house than open field. The response to fertilisers however differs. Application of $10 \mathrm{t} / \mathrm{ha} \mathrm{MSC}$ and $50 \mathrm{Kg} \mathrm{N} / \mathrm{ha}$ increased the stem girth under screen house and field conditions (Table 3). In the case of leaf area, all the vegetables especially, Solanum vegetables, responded better under screenhouse than open field. A. cruentus grown under screen-house performed better than open field and recorded the highest value in MSC treatment at $10 \mathrm{t} / \mathrm{ha}$. On the field, application of NPK at $100 \mathrm{Kg} \mathrm{N} /$ ha gave the highest leaf area. In C. argentea, leaf area was also enhanced under screen

Table 1: Effects of compost and NPK fertilizer on the number of leaves of the vegetables under the two experimental conditions.

\begin{tabular}{|c|c|c|c|c|c|}
\hline \multirow[t]{2}{*}{ Treatments } & \multicolumn{2}{|c|}{ Screen house } & \multicolumn{3}{|c|}{ Open field } \\
\hline & 2WAS & 4WAS 6WAS & 2WAS & 4WAS & 6WAS \\
\hline A. C Control & $10.3 a$ & $12.3 \mathrm{a} \quad 17.0 \mathrm{a}$ & $6.66 \mathrm{bc}$ & $10.3 \mathrm{abc}$ & $=13.0 \mathrm{ab}$ \\
\hline A. C+MSC (5ton/ha) & $6.66 \mathrm{bc}$ & $8.66 b c 13.6 a$ & $8.00 a$ & $11.0 \mathrm{ab}$ & $14.3 a b$ \\
\hline A. C+MSC (10ton/ha) & $9.00 a b$ & $10.0 \mathrm{~b} \quad 14.3 \mathrm{a}$ & $7.00 \mathrm{abc}$ & $=11.3 \mathrm{a}$ & $15.0 \mathrm{ab}$ \\
\hline A. C+NPK $(50 \mathrm{kgN} / \mathrm{ha})$ & $9.33 a b$ & $11.3 \mathrm{ab} \mathrm{14.6a}$ & $8.00 a$ & $11.3 \mathrm{a}$ & $15.3 a$ \\
\hline A. C+NPK( $100 \mathrm{kgN} / \mathrm{ha})$ & $8.00 a b$ & $11.0 \mathrm{ab} 13.6 \mathrm{a}$ & $7.66 a b$ & $11.0 \mathrm{ab}$ & $15.3 a$ \\
\hline C. A Control & $7.66 a$ & $12.6 a \quad 14.3 a$ & $10.6 \mathrm{a}$ & $12.0 \mathrm{a}$ & $14.0 \mathrm{a}$ \\
\hline C. A+MSC (5ton/ha) & $6.33 \mathrm{abc}$ & $12.6 \mathrm{a} 14.6 \mathrm{a}$ & $9.00 \mathrm{ab}$ & $10.0 \mathrm{bc}$ & $12.0 \mathrm{bc}$ \\
\hline C. A+MSC (10ton/ha) & 6.66ab & $11.6 \mathrm{ab} \mathrm{14.6a}$ & $11.0 \mathrm{a}$ & $13.0 \mathrm{a}$ & $14.6 \mathrm{a}$ \\
\hline C. A+NPK $(50 \mathrm{kgN} / \mathrm{ha})$ & $5.33 b c$ & $12.3 \mathrm{ab} \mathrm{14.0a}$ & $9.33 a b$ & $10.3 a b$ & $13.0 \mathrm{ab}$ \\
\hline C. A+NPK $(100 \mathrm{kgN} / \mathrm{ha})$ & $7.00 \mathrm{a}$ & $14.0 \mathrm{a} \quad 15.3 \mathrm{a}$ & $7.66 \mathrm{bc}$ & $10.6 a b$ & $13.3 a b$ \\
\hline S. I Control & $3.33 b$ & $6.00 \mathrm{~b} 8.00 \mathrm{~b}$ & $1.33 \mathrm{bc}$ & $3.66 a b$ & $7.66 \mathrm{ab}$ \\
\hline S. I+MSC (5ton/ha) & $3.66 a$ & $6.00 b 8.33 a$ & $1.66 \mathrm{a}$ & $4.00 \mathrm{a}$ & $7.66 a b$ \\
\hline S. I+MSC (10ton/ha) & $3.33 b$ & $6.66 a 7.33 b$ & $2.00 \mathrm{a}$ & $3.33 a b c$ & $8.6 a$ \\
\hline S. I NPK ( $50 \mathrm{kgN} / \mathrm{ha})$ & $3.66 \mathrm{a}$ & $5.33 b c 8.66 a$ & $1.66 b$ & $3.00 \mathrm{bc}$ & $7.00 \mathrm{bc}$ \\
\hline S. I NPK (100kg N/ha) & $3.33 b$ & $6.00 \mathrm{~b} 7.66 \mathrm{~b}$ & $1.66 \mathrm{~b}$ & $3.66 a b$ & $7.00 \mathrm{bc}$ \\
\hline S. M Control & $4.33 a$ & $5.66 \mathrm{a} 7.00 \mathrm{~b}$ & $2.66 b$ & $5.00 \mathrm{~b}$ & $6.00 \mathrm{~b}$ \\
\hline S. M+MSC (5ton/ha) & $4.33 a$ & $5.33 b 6.66 b c$ & $3.33 b$ & $6.66 \mathrm{a}$ & $8.00 \mathrm{a}$ \\
\hline S. M+MSC (10ton/ha) & $4.66 a$ & $6.00 a 7.33 a$ & $3.66 a$ & $5.66 b$ & $7.66 a$ \\
\hline S. M NPK $(50 \mathrm{kgN} / \mathrm{ha})$ & $4.00 b$ & $6.00 \mathrm{a} 7.00 \mathrm{~b}$ & $3.66 a$ & $6.66 a$ & $7.66 a$ \\
\hline S. M NPK (100kgN/ha) & $4.00 \mathrm{~b}$ & $5.00 b c 7.33 a$ & $3.33 b$ & $7.66 \mathrm{a}$ & $8.33 a$ \\
\hline S. N Control & $3.00 \mathrm{~b}$ & $4.33 b c 7.33 b$ & $1.33 b$ & $3.66 b$ & $7.66 a$ \\
\hline S. N+MSC (5ton/ha) & $3.00 b$ & $5.33 b \quad 8.33 b$ & $1.66 \mathrm{a}$ & $4.00 a$ & $7.66 \mathrm{a}$ \\
\hline S. N+MSC (10ton/ha) & $4.33 a$ & $7.00 a 8.66 b$ & $2.00 \mathrm{a}$ & $4.00 \mathrm{a}$ & $8.66 a$ \\
\hline S. N NPK $(50 \mathrm{kgN} / \mathrm{ha})$ & $4.33 a$ & $7.00 \mathrm{a} 8.66 \mathrm{~b}$ & $1.66 \mathrm{a}$ & $3.33 \mathrm{bc}$ & $7.00 \mathrm{~b}$ \\
\hline S. N NPK (100kgN/ha) & $4.00 \mathrm{a}$ & $6.66 a 8.66 b$ & $1.66 a$ & $3.66 b$ & $7.00 \mathrm{~b}$ \\
\hline
\end{tabular}

Means followed by the same letter in a column are not significantly different from each other at $\mathrm{P}<0.05$ by $\mathrm{DMRT}$. A.C $=$ Amaranthus cruentus, C.A $=$ Celosia aregentea, $\mathrm{S} . \mathrm{M}=$ Solanum macrocarpon, $\mathrm{S} . \mathrm{I}=$ Solanum incanum, $\mathrm{S} . \mathrm{N}=$ Solanum nigrum, MSC $=$ Mexican Sunflower Compost 
Table 2. Effects of compost and NPK fertilizer on the Plant Height $(\mathrm{cm})$ of the vegetables under the two experimental conditions.

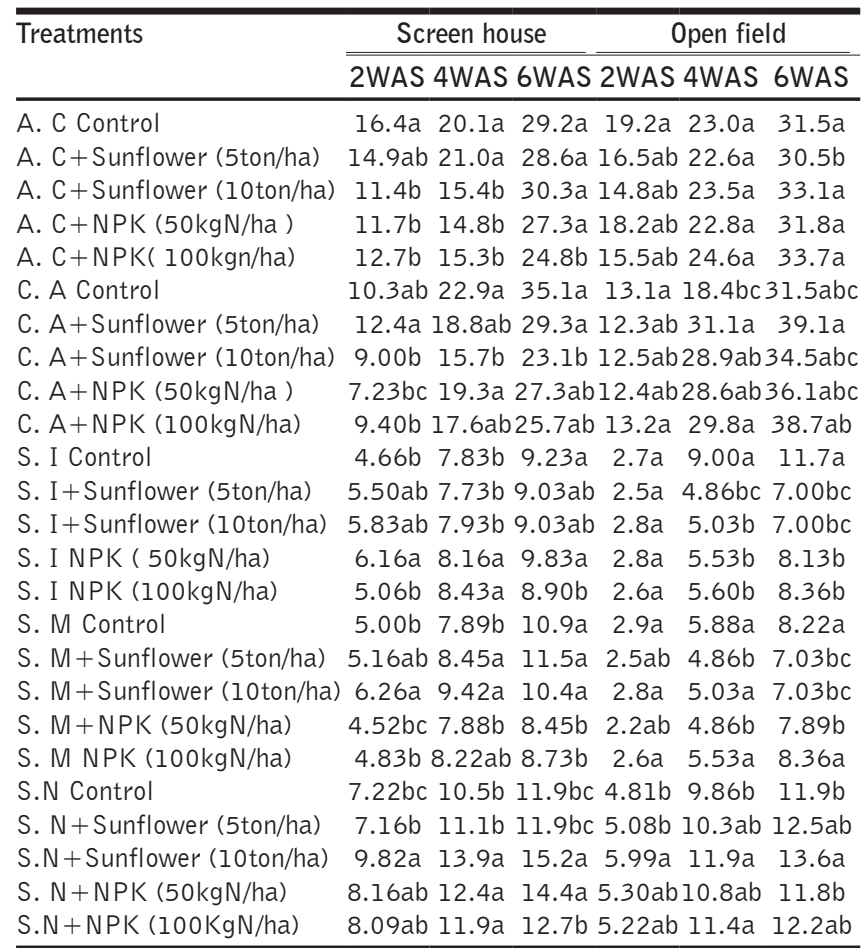

Means followed by the same letter in a column are not significantly different from each other at $\mathrm{P}<0.05$ by DMRT. A. $\mathrm{C}=$ Amaranthus cruentus, C.A $=$ Celosia aregentea, $\mathrm{S} . \mathrm{M}=$ Solanum macrocarpon, $\mathrm{S} . \mathrm{I}=$ Solanum incanum, $\mathrm{S} . \mathrm{N}=$ Solanum nigrum, MSC = Mexican Sunflower Compost.

house conditions but application of $100 \mathrm{Kg} \mathrm{N} / \mathrm{ha}$ gave the highest value at 4 and 6 WAS. Though, slow growing vegetable, there was exponential and considerable increase in the leaf area of all the Solanum varieties in the screen house compared to open field and was more than double the values obtained in the open field especially at 6 WAS. Leaf area production was enhanced in the amended soils compared to the control both in the screen-house and the open field conditions. The least value for leaf area was recorded in the control treatments. S. nigrum in comparison with the other $\mathrm{S}$. species had the highest mean value for leaf area under screen-house in response to MSC at $10 \mathrm{t} / \mathrm{ha}$ and NPK at $100 \mathrm{KgN} / \mathrm{ha}$. Generally, the leaf areas of all the vegetables increased across all the treatments at 6WAP under both experimental conditions (Table 4).

\section{Effects of Mexican Sunflower Compost and NPK Fertiliser on the Chlorophyll Contents of the Vegetables Under the Two Experimental Conditions}

Chlorophyll production was enhanced in the screen-house conditions compared to the open field. It also increased as the plant ages. In A. cruentus, at 4 and 6 WAS, under screenhouse, control performed better than fertiliser treatments except at 6 WAS under open field when MSC treatment at $5 \mathrm{t} /$ ha gave the highest value but not significantly different from other treatments. Screen-house conditions also increased
Table 3. Effects of compost and NPK fertilizer on the Stem Girth $(\mathrm{cm})$ of the vegetables under the two experimental conditions.

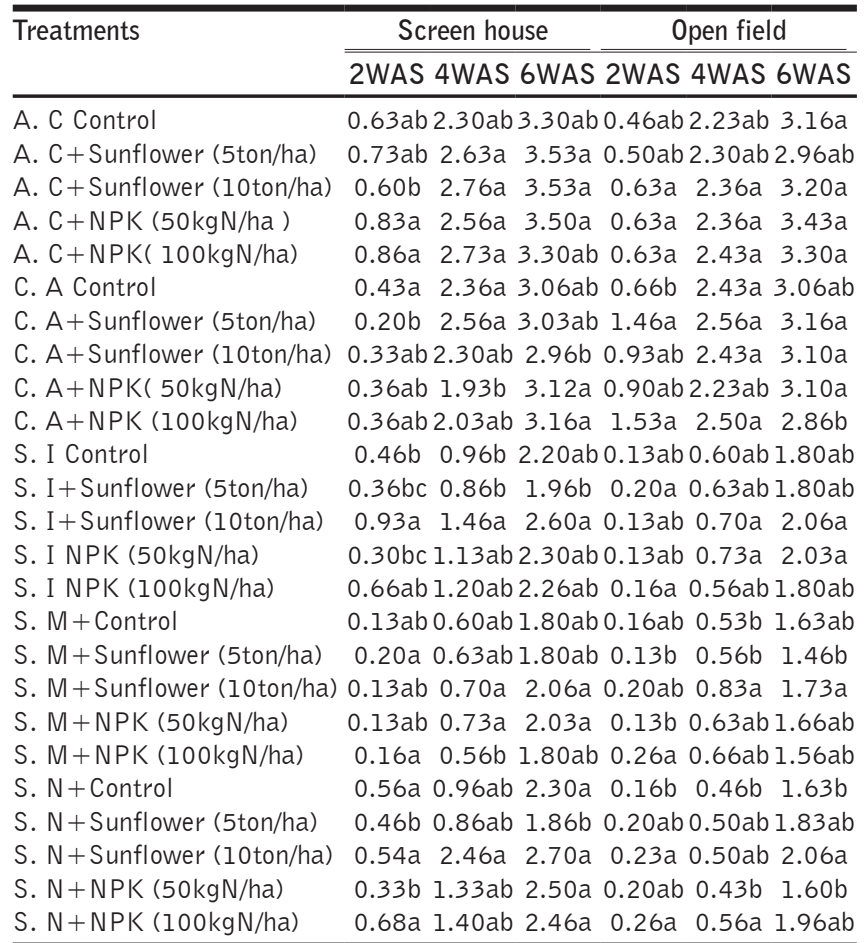

Means followed by the same letter in a column are not significantly different from each other at $\mathrm{P}<0.05$ by DMRT. $\mathrm{A} . \mathrm{C}=$ Amaranthus cruentus, C.A = Celosia aregentea, $\mathrm{S} . \mathrm{M}=$ Solanum macrocarpon, $\mathrm{S} . \mathrm{I}=$ Solanum incanum, $\mathrm{S} . \mathrm{N}=$ Solanum nigrum, $\mathrm{MSC}=$ Mexican Sunflower Compost.

the chlorophyll contents of $\mathrm{C}$. argentea compared to open field. C. argentea treated with NPK $50 \mathrm{kgN} / \mathrm{ha}$ in the screen-house had the highest amount of chlorophyll compared to other treatments at 6 WAS while, control plants had the highest chlorophyll concentration in the open field at 6 WAS. In terms of chlorophyll production, the $\mathrm{S}$. varieties also showed higher chlorophyll concentrations in the screen-house compared to open field across all the treatments and in comparison to the other vegetables. Specifically, S. macrocarpon grown in the screen-house with NPK had the highest mean value, followed by the control which had no soil amendment, but on the field, application of MSC at 5t/ha gave the highest value of chlorophyll. S. incanum also responded positively to NPK fertiliser and had the highest chlorophyll concentration in this treatment (Table 6).

\section{Total Fresh and Dry Weight of the Harvested Vegetables}

The total fresh and dry weights recorded for all the vegetables at harvesting showed that growing vegetables under screen-house conditions favours biomass accumulation compared to open field. The total fresh and dry weights recorded for C. argentea showed that it had more weight in the screen-house than openfield. In the screen-house, the fresh weight was $110 \mathrm{~g}$, and its dry weight was $58 \mathrm{~g}$, while in the open-field its fresh weight was $78 \mathrm{~g}$ and its dry weight was $26 \mathrm{~g}$. A. cruentus also had fresh and dry weights of 107 and $44 \mathrm{~g}$, respectively in the screen-house, while 
Table 4. Effects of compost and NPK fertilizer on the leaf area $\left(\mathrm{cm}^{2}\right)$ of the vegetables under the two experimental conditions.

\begin{tabular}{|c|c|c|}
\hline \multirow[t]{2}{*}{ Treatments } & Screen house & Open field \\
\hline & 2WAS 4WAS & 6WAS 2WAS 4WAS 6WAS \\
\hline C Control & $9.56 b$ 24.0ab & $38.6 b$ 10.2ab21.0ab 29.9b \\
\hline A. $C+$ Sunflower (5ton/ha) & $16.3 a \quad 26.5 a$ & 39.1b 10.0ab20.4ab 31.4a \\
\hline A. C+Sunflower (10ton/ha) & $10.8 b \quad 28.7 a$ & $\begin{array}{llll}48.5 a & 14.9 a & 23.5 a & 30.8 a b\end{array}$ \\
\hline A. C+NPK $(50 \mathrm{kgN} / \mathrm{ha})$ & 12.8ab 23.5ab & 42.7ab 10.8ab 23.3a 30.0ab \\
\hline A. $C+N P K(100 \mathrm{kgN} / \mathrm{ha})$ & $12.0 a b 20.7 b$ & 44.1ab 13.5a 22.7ab 34.3a \\
\hline C. A Control & $8.06 b 26.8 a b$ & 48.6ab 7.49ab 18.4b 31.5ab \\
\hline C. A+Sunflower (5ton/ha) & $9.88 a b 21.8 a b$ & 41.6ab8.75ab 31.0a 39.1a \\
\hline C. A+Sunflower (10ton/ha) & 8.48ab 22.8ab & 33.0b 7.50ab28.9ab34.5ab \\
\hline C. A+NPK( $50 \mathrm{kgn} / \mathrm{ha})$ & $8.17 b \quad 38.6 a$ & 40.2ab 9.42a 28.6ab36.1ab \\
\hline C. A+NPK $(100 \mathrm{kgN} / \mathrm{ha})$ & $13.5 \mathrm{a} \quad 33.5 \mathrm{a}$ & 53.2a 9.11a 29.8ab 38.7a \\
\hline S. I Control & $5.27 b \quad 15.3 b c$ & 78.1b 5.29a 15.3ab 24.1b \\
\hline S. I+Sunflower & $4.05 c 13.6 b c$ & 86.3ab 4.73ab 13.6b 27.7ab \\
\hline S. I+Sunflower (10ton/ha) & $5.14 b \quad 17.2 b$ & 85.2ab 4.97ab17.2ab 21.7b \\
\hline S. I NPK ( & $10.0 a \quad 20.9 a$ & $89.7 a$ 4.21a 15.4ab24.8ab \\
\hline S. I NPK $(100 \mathrm{kgN} / \mathrm{ha})$ & $5.32 b \quad 20.7 a$ & $92.4 a \quad 5.32 a \quad 20.5 a \quad 32.5 a$ \\
\hline S. M Control & $10.3 a b 34.1 a$ & 68.4b 13.5ab35.0ab52.1ab \\
\hline S. M+Sunflower (5ton/ha) & $13.4 \mathrm{a} \quad 38.4 \mathrm{a}$ & $89.3 a b$ 16.2a 29.4ab46.7ab \\
\hline S. M + Sunflower (10ton/ha) & $11.2 \mathrm{a} \quad 39.6 \mathrm{a}$ & $77.3 b \quad 11.1 b \quad 35.6 a$ 56.0ab \\
\hline S. M NPK (50l & $11.6 \mathrm{a} \quad 38.6 \mathrm{a}$ & 91.8a 14.0ab33.1ab 61.3a \\
\hline S. M NPK (100kgN/ha) & $10.4 a b 34.4 a$ & $88.6 a b 13.9 a b 28.8 b 50.6 a b$ \\
\hline S. N Control & $19.9 b \quad 28.5 d$ & 34.6c 5.80a 16.7ab36.8ab \\
\hline S. N+Sunflower (5ton/ha) & $24.1 \mathrm{ab} 61.1 \mathrm{bcd}$ & 78.0b 4.73ab15.5ab38.5ab \\
\hline S. N+Sunflower (10ton/ha) & 27.9 ab 92.9 & 103.6a 5.02a 16.4ab 40.9a \\
\hline S. N N & $33.0 a \quad 80.6 b c$ & 97.8ab 4.62ab15.5ab38.5ab \\
\hline S. N NPK $(100 \mathrm{kgN} / \mathrm{ha})$ & $39.1 \mathrm{a} 13$ & 159.0a4.63ab 17.7a 44.4a \\
\hline
\end{tabular}

Means followed by the same letter in a column are not significantly different from each other at $\mathrm{P}<0.05$ by DMRT. A. $\mathrm{C}=$ Amaranthus cruentus, C.A = Celosia aregentea, $\mathrm{S} . \mathrm{M}=$ Solanum macrocarpon, $\mathrm{S} . \mathrm{I}=$ Solanum incanum, $\mathrm{S} . \mathrm{N}=$ Solanum nigrum, $\mathrm{MSC}=$ Mexican Sunflower Compost.

in the open-field, it had fresh weight of $54 \mathrm{~g}$ and dry weight of $19 \mathrm{~g}$. A. spinosus followed next with fresh weight of $92 \mathrm{~g}$ and dry weight of $30 \mathrm{~g}$ in the screen-house while in the open-field it had fresh weight of $48 \mathrm{~g}$ and dry weight of $18 \mathrm{~g}$. S. macrocarpon followed the same trend and had fresh weight of $59 \mathrm{~g}$ and dry weight of $28 \mathrm{~g}$ in the screen-house while in the open-field, it recorded fresh weight of $25 \mathrm{~g}$ and dry weight of $12 \mathrm{~g}$. Then $\mathrm{S}$. incanum in the screen-house recorded fresh weight of $42 \mathrm{~g}$ and dry weight of $19 \mathrm{~g}$, while in the open-field, it had fresh weight of $14 \mathrm{~g}$ and dry weight of $9 \mathrm{~g}$. S. nigrum also had more of fresh and dry weights in the screen-house compared to open-field which were $38 \mathrm{~g}$ and $20 \mathrm{~g}$ in the screen-house and in the open-field, fresh weight of $25 \mathrm{~g}$ and dry weight of $12 \mathrm{~g}$ (Figure 1).

\section{Effects of Mexican Sunflower Compost and NPK Fertiliser on the Moisture and Ash Contents of the Vegetables Under Both Experimental Conditions}

Mexican sunflower compost increased the moisture contents of Solanum vegetables both in the screen-house and open field compared to NPK fertiliser, while, application of $100 \mathrm{kgN} / \mathrm{ha}$ of NPK fertiliser to both C. argentea and A. cruentus gave the highest moisture content. There was no significant difference in the moisture contents of S. incanum at $100 \mathrm{kgNha}$ and control (Figure 2). Celosia argentea grown on the open field with the
Table 5. Effects of compost and NPK fertilizer on the chlorophyll content $(\mu \mathrm{g} / \mathrm{g} \mathrm{FW})$ of the vegetables under the two experimental conditions.

\begin{tabular}{|c|c|c|}
\hline \multirow[t]{2}{*}{ Treatments } & Screen house & Open field \\
\hline & \multicolumn{2}{|c|}{ 2WAS 4WAS 6WAS 2WAS 4WAS 6WAS } \\
\hline C Control & $26.8 a b 40.5 a \quad 47.9 a$ & $21.9 \mathrm{a} 33.2 \mathrm{ab} 35.4 \mathrm{ab}$ \\
\hline C + Sunflower (5ton/ha) & $24.8 b \quad 35.0 a b 44.7$ & $19.3 a b 32.0 a b 38.5 a$ \\
\hline . C + Sunflower (10ton/ha) & $27.4 a \quad 36.9 a \quad 44.8 a b$ & $22.1 \mathrm{a} 31.5 \mathrm{ab} 29.9 \mathrm{~b}$ \\
\hline . C + NPK( $50 \mathrm{kgN} / \mathrm{ha})$ & $26.8 a b 37.7 a$ 43.1ab & $21.1 \mathrm{a} 33.9 \mathrm{a} \quad 37.5 \mathrm{a}$ \\
\hline C + NPK( $100 \mathrm{kgN} / \mathrm{ha})$ & $27.9 a$ 35.1ab 44.2ab & 20.8a 32.1ab 35.5ab \\
\hline C. A Control & $41.2 \mathrm{a} \quad 41.3 \mathrm{a} 44.5 \mathrm{ab}$ & $34.1 a$ 35.4ab 42.9a \\
\hline C. A+Sunflower (5ton/ha) & $35.1 a b 35.5 a b 43.4 a b$ & $30.0 a \quad 36.8 a \quad 40.7 a$ \\
\hline C. A+Sunflower (10ton/ha) & $38.2 \mathrm{a} \quad 39.5 \mathrm{a} \quad 41.9 \mathrm{~b}$ & $23.6 \mathrm{c} 33.5 \mathrm{ab} 37.2 \mathrm{ab}$ \\
\hline C. A+NPK $(50 \mathrm{kgN} / \mathrm{ha})$ & $29.3 b \quad 39.8 a \quad 44.9 a$ & 26.1b 35.4ab 38.0ab \\
\hline C. A+NPK (100kgN/ha) & $29.4 b \quad 39.5 a \quad 42.3 a b$ & $28.8 b \quad 36.0 a$ 38.7ab \\
\hline S. I Control & 25.5a 37.1a 52.1ab & $22.4 a b 25.1 b \quad 41.6 a$ \\
\hline S. I+Sunflower (5ton/ha) & $26.5 a$ 35.1ab 48.9b & $21.7 b \quad 27.9 a \quad 39.8 a b$ \\
\hline S. I+Sunflower (10ton/ha) & $25.7 a$ 35.1ab 49.8b & $22.8 a b 27.4 a$ 38.9ab \\
\hline S. I NPK (50kgN/ha) & $27.4 a$ 35.4ab 52.5ab & $25.4 a \quad 27.5 a \quad 34.3 a b$ \\
\hline S. I NPK $(100 \mathrm{kgN} / \mathrm{ha})$ & 28.0a 35.8ab 53.5a & $25.0 a \quad 27.5 a \quad 31.5 b$ \\
\hline S. M Control & 45.3ab 49.0a 51.1ab & 36.6ab 37.3ab 42.6ab \\
\hline S. M + Sunflower (5ton/ha) & $49.9 a \quad 48.7 a b 49.2 a$ & 37.0ab 44.2a 47.5a \\
\hline S. M + Sunflower (10ton/ha) & $45.6 a b 46.6 a b 51.1 a$ & 37.2ab 38.1ab 43.4ab \\
\hline S. M NPK $(50 \mathrm{kgN} / \mathrm{ha})$ & 45.9ab 47.5ab 52.6a & 33.8ab 38.8ab 43.4ab \\
\hline S. M NPK (100kgN/ha) & $50.0 a \quad 49.9 a \quad 52.3 a b$ & $39.8 a 32.1 b c 42.6 a b$ \\
\hline S. N Control & $25.3 a b 45.9 a \quad 52.3 a$ & $21.4 a$ 32.6ab 32.6ab \\
\hline S. N+Sunflower (5ton/ha) & $28.8 a$ 40.9ab 50.0ab & $24.1 \mathrm{a} 36.8 \mathrm{a} \quad 36.2 \mathrm{a}$ \\
\hline S. N+Sunflower (10ton/ha) & 25.1ab 42.1ab 50.0ab & $21.4 \mathrm{a} 31.2 \mathrm{ab} 31.5 \mathrm{ab}$ \\
\hline DK $(50 \mathrm{kgN} / \mathrm{ha}$ & $25.8 a b 41.3 a b 48.8 a b$ & $21.6 a$ 32.9ab 32.1b \\
\hline S. N NPK $(100 \mathrm{kgN} / \mathrm{ha})$ & $26.8 a b 41.3 a b 50.0 a b$ & $23.1 \mathrm{a} 32.5 \mathrm{ab} 29.8 \mathrm{c}$ \\
\hline
\end{tabular}

Means followed by the same letter in a column are not significantly different from each other at $\mathrm{P}<0.05$ by DMRT. $\mathrm{A} . \mathrm{C}=$ Amaranthus cruentus, C. $\mathrm{A}=$ Celosia aregentea, $\mathrm{S} . \mathrm{M}=$ Solanum macrocarpon, $\mathrm{S} . \mathrm{I}=$ Solanum incanum, $\mathrm{S} . \mathrm{N}=$ Solanum nigrum, $\mathrm{MSC}=$ Mexican Sunflower Compost.

application of $100 \mathrm{kgN} / \mathrm{ha}$ NPK fertiliser had the highest ash content, while control had the highest ash content in the screen-house. S. macrocarpon had the least ash content with the application of $100 \mathrm{kgN} / \mathrm{ha}$ under both experimental conditions. S. nigrum and S. macrocarpon at $10 \mathrm{t} /$ ha compost had higher ash contents than with the application of NPK. It was observed that the Solanum varieties grown on soil without amendments also had higher ash contents than those treated with NPK. A. cruentus was observed to have the highest ash contents with the application of $100 \mathrm{kgN} / \mathrm{ha}$ both in the screen-house and open field while control had the least ash content only on the field. Meanwhile at $10 \mathrm{t} / \mathrm{ha}$, compost application to A. cruentus gave the least ash content in the screen-house. Generally, the ash contents of the Solanum vegetables was enhanced in the screenhouse more than open field and with the application of compost (Figure 3).

\section{Effects of Mexican Sunflower Compost and NPK Fertiliser on the Crude Protein Contents of the Vegetables Under Both Experimental Conditions}

As observed for the moisture and ash content, crude protein content was also enhanced under screen-house than open field. The result showed that soil amendments with NPK fertiliser at $100 \mathrm{kgN} /$ ha increased the crude protein content of C. argentea vegetable on the field, while in the screen-house, soil 


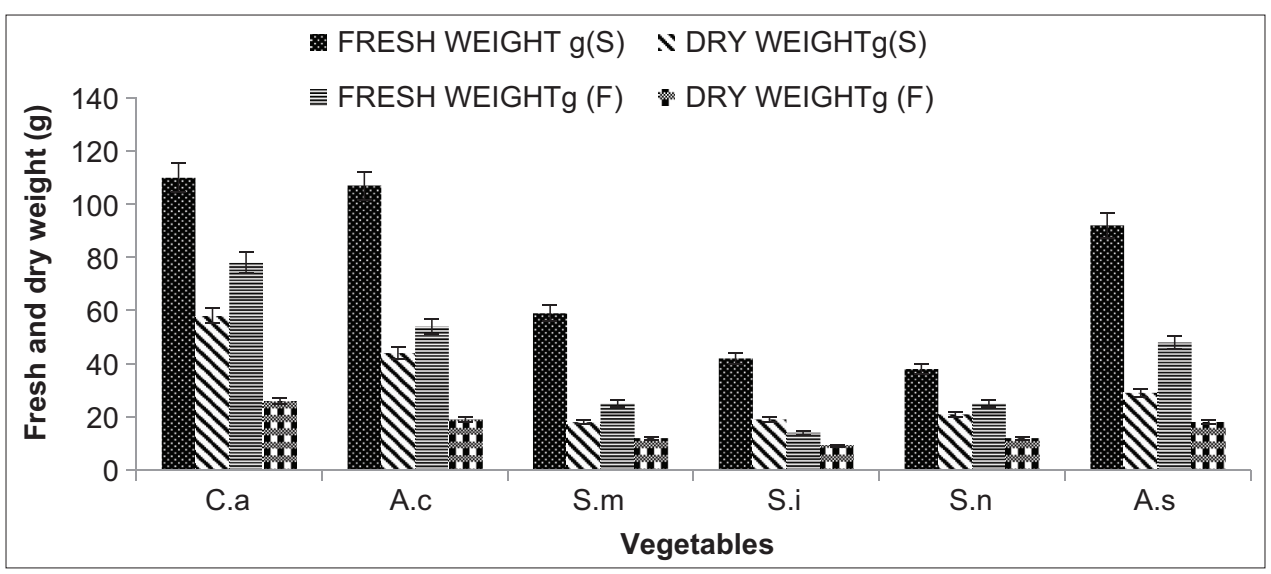

Figure 1: Total fresh and dry weights of the harvested vegetables.(C.a, A.c, S.m, S.i and S.n denote Celosia aregentea, Amaranthus cruentus Solanum macrocarpon, Solanum incanum and Solanum nigrum respectively (Bars of chart represent $5 \%$ Standard Error)

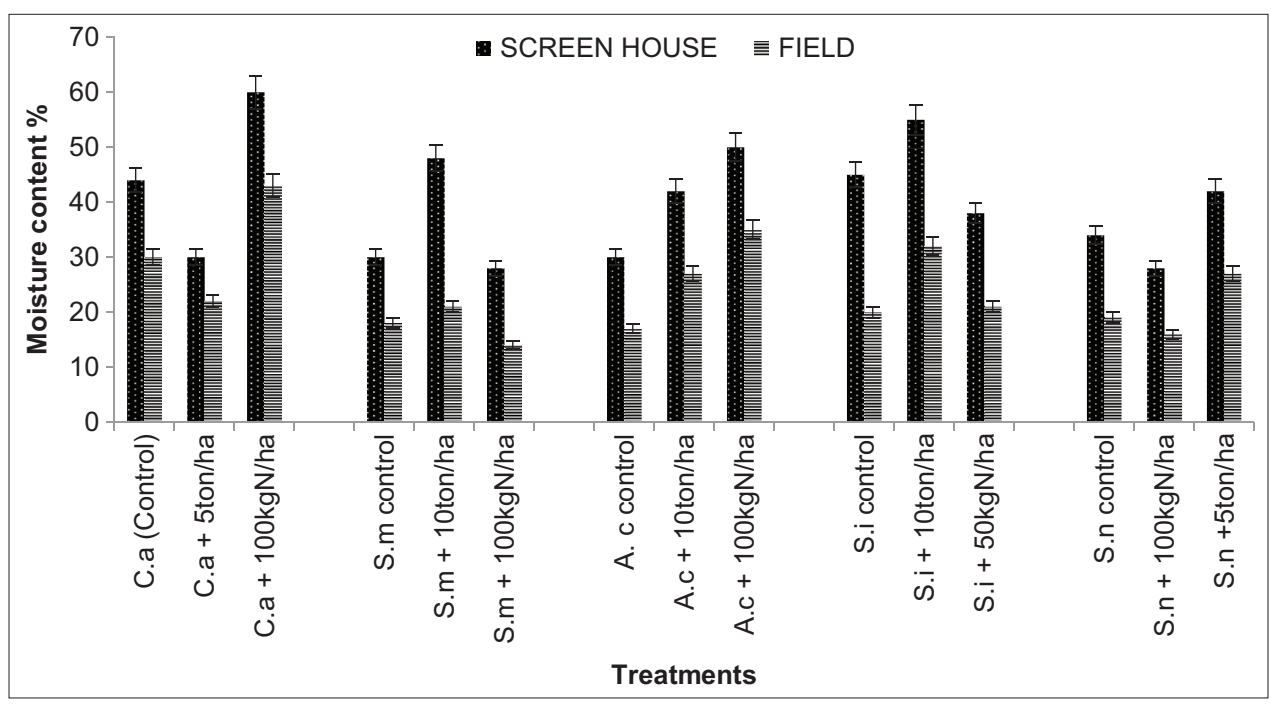

Figure 2: Effects of the treatments on the moisture contents of the vegetables under the two experimental conditions. (C.a, A.c, S.m, S.i and S.n denote Celosia aregentea, Amaranthus cruentus Solanum macrocarpon, Solanum incanum and Solanum nigrum respectively (Bars of chart represent 5\% Standard Error)

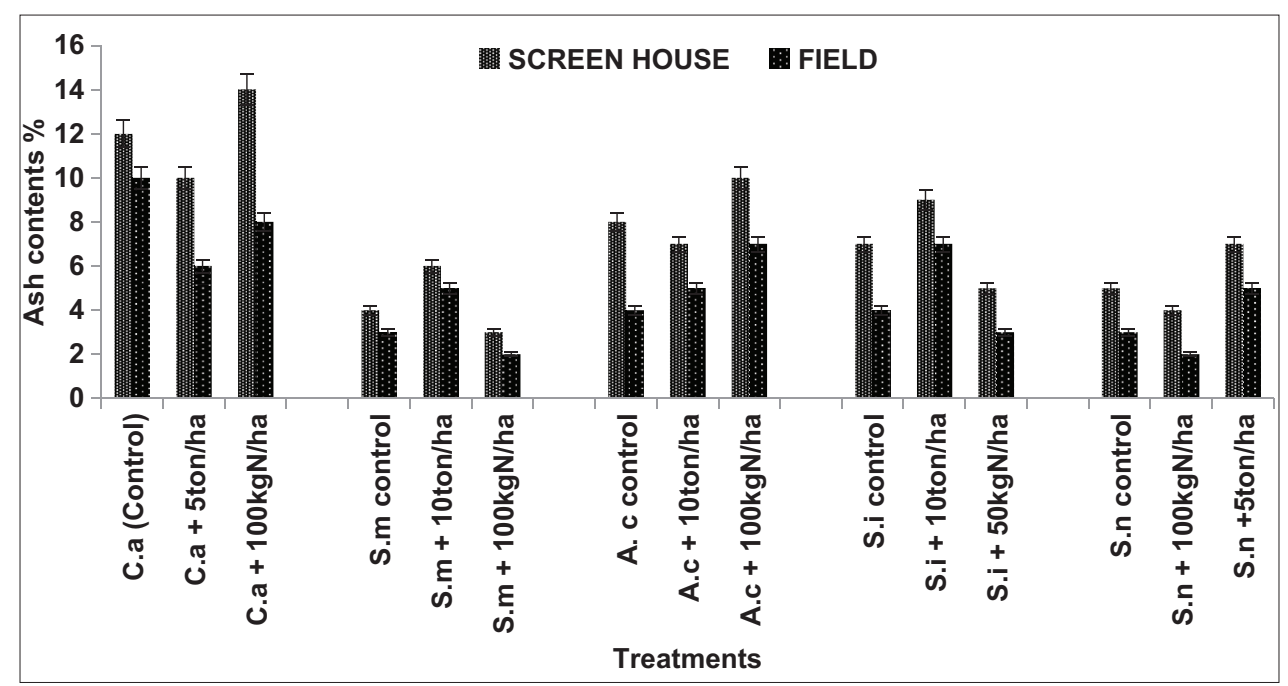

Figure 3: Effects of the treatments on the ash contents of the vegetables under both experimental conditions. (C.a, A.c, S.m, S.i and S.n denote Celosia aregentea, Amaranthus cruentus Solanum macrocarpon, Solanum incanum and Solanum nigrum respectively (Bars of chart represent $5 \%$ Standard Error) 


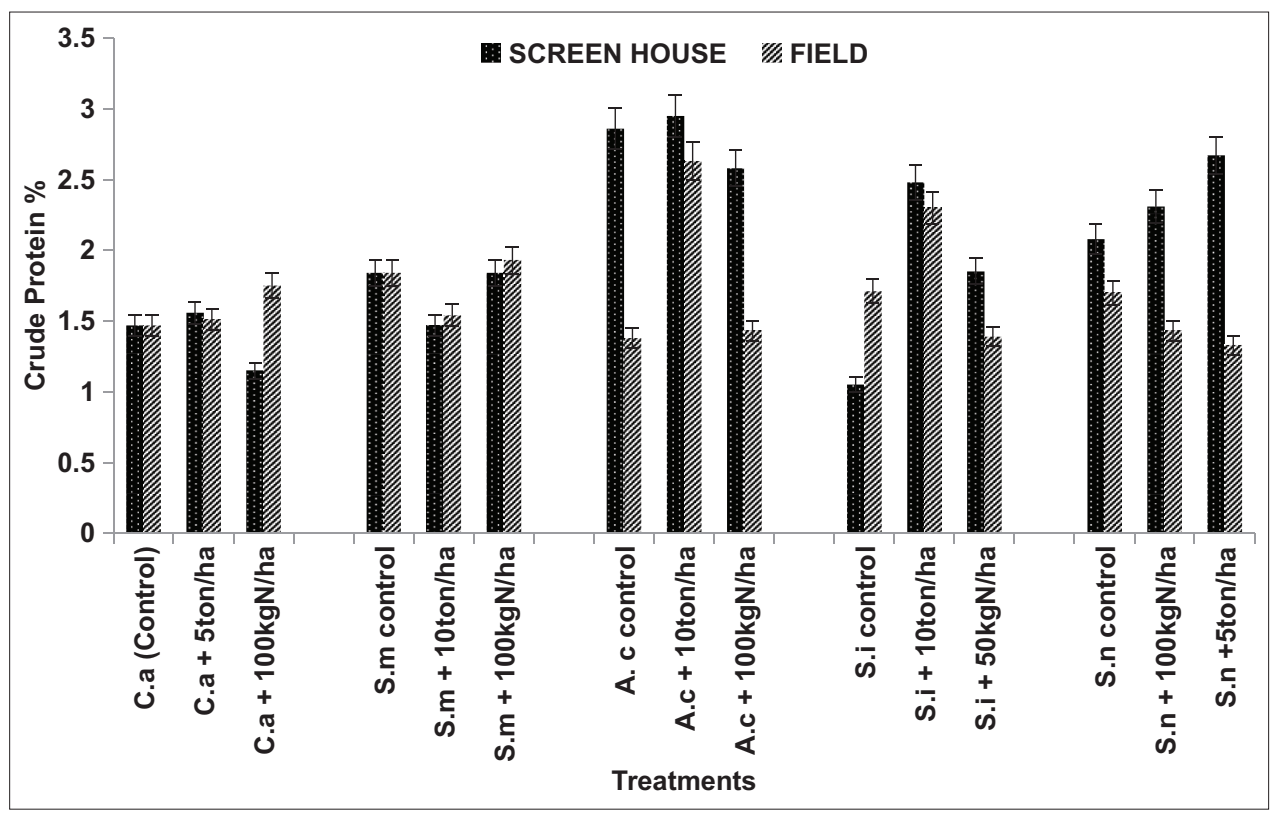

Figure 4: Effects of the treatments on the crude protein contents of the vegetables under both experimental conditions. (C.a, A.c, S.m, S.i and S.n denote Celosia aregentea, Amaranthus cruentus Solanum macrocarpon, Solanum incanum and Solanum nigrum respectively (Bars of chart represent $5 \%$ Standard Error).

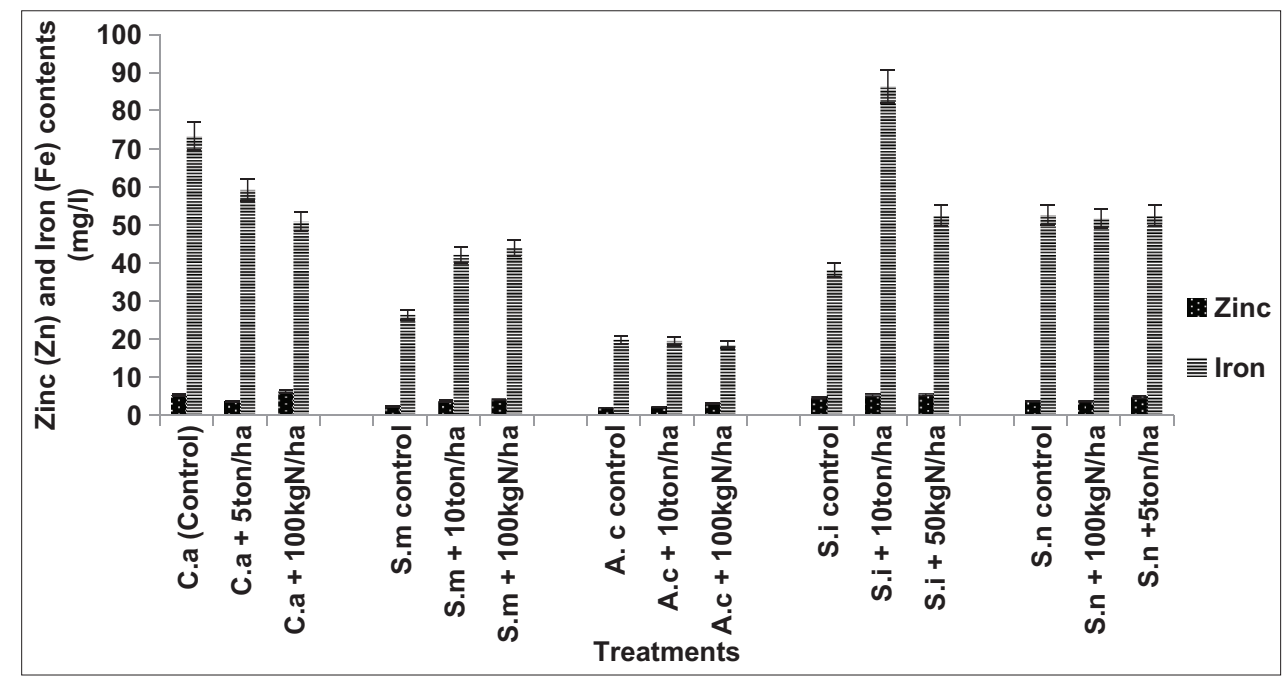

Figure 5: Effects of Mexican sunflower compost and NPK fertilizer on the Zinc and Iron concentrations of the vegetables in the screen-house (C.a, A.c, S.m, S.i and S.n denote Celosia aregentea, Amaranthus cruentus Solanum macrocarpon, Solanum incanum and Solanum nigrum respectively (Bars of chart represent $5 \%$ Standard Error)

amendment with compost at $5 \mathrm{t} / \mathrm{ha}$ increased the crude protein. In both experimental conditions, there was no significant difference in soils without amendments. The crude protein was significantly enhanced by compost at 10 t/ha for A. cruentus both in the screen-house and on the field. S. incanum grown on soil without amendment had the least crude protein produced, while 10 t/ha sunflower compost gave the highest crude protein production. On the other hand, $100 \mathrm{kgN} / \mathrm{ha}$ significantly increased the crude protein of $S$. macrocarpon and there was no significant difference in the control. The application of $10 \mathrm{t} / \mathrm{ha}$ sunflower compost, gave the least crude protein mean values. Organic amendment at $5 \mathrm{t} / \mathrm{ha}$ gave a significantly high crude protein in S. nigrum vegetable grown in the screen-house, while in the open-field, control which is the soil without amendment had the highest value (Fig 4).

\section{Effects of Mexican Sunflower Compost and NPK} fertiliser on the zinc and iron contents of the vegetables in the screen-house

Ceosia argentea with the application of $50 \mathrm{kgN} / \mathrm{ha}$ NPK had the highest iron and zinc contents, while soil with the application of $5 \mathrm{t}$ /ha compost gave the lowest zinc and iron contents. S. macrocarpon grown on the soil without amendments had the highest iron contents, and there was no significant difference in the zinc concentrations across all the treatments. Meanwhile, 


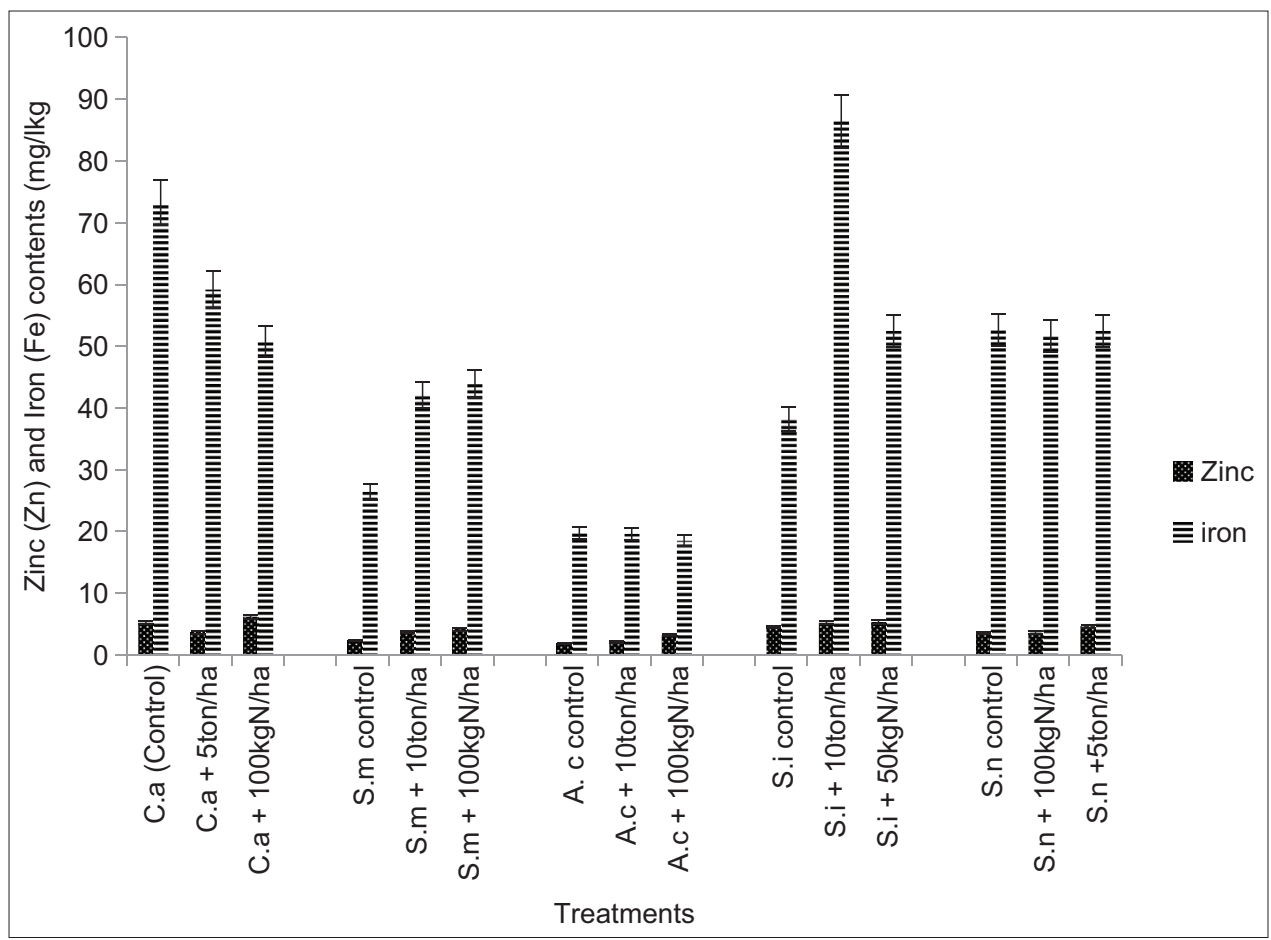

Figure 6: Effects of Mexican sunflower compost and NPK fertilizer on the Zinc and Iron concentrations of the vegetables under the open-field. (C.a, A.c, S.m, S.i and S.n denote Celosia aregentea, Amaranthus cruentus Solanum macrocarpon, Solanum incanum and Solanum nigrum respectively (Bars of chart represent $5 \%$ Standard Error)

with the application of $10 \mathrm{t} / \mathrm{ha}$ compost to A. cruentus, iron content was enhanced while control had the lowest, and there was no significant difference in the zinc contents across all the treatments. Soil without amendment for both S. incanum and $S$. nigrum vegetables had the highest iron concentrations, followed by soil with the application of $10 \mathrm{t} / \mathrm{ha}$ compost. There were no significant differences in the zinc contents of both S. incanum and $S$. nigrum vegetables across all the treatments (Fig 5). Application of $100 \mathrm{kgN} / \mathrm{ha}$ to Celosia vegetable gave the least iron content and highest zinc content, while the control had the highest iron content, followed by the soil with the application of $5 \mathrm{t} / \mathrm{ha}$. S. macrocarpon treated with the application of $100 \mathrm{kgN} / \mathrm{ha}$ NPK had the highest iron content while the control had the lowest, but there were no significant difference in the zinc content across the treatments. Similarly, there were no significant difference in both the zinc and iron contents across all the treatments of A. cruentus. With the application of $10 \mathrm{t} / \mathrm{ha}$ compost gave the highest iron content, while the control plant had the least iron content. There were no significant difference in the zinc content across all the treatments. No significant difference in both the zinc and iron contents of S. nigrum (Fig 6).

\section{DISCUSSION}

The environmental factors such as relative humidity, temperature and light intensity are known for controlling plant evapo-transpiration and this has significant effect on crop growth and development. Light intensity determines the relative humidity, temperature and plant transpiration rate. The result of this study showed clearly the importance of reduced light intensity on vegetable production and the potential of fertilisers especially the Mexican sunflower compost in improving vegetable production under different growing conditions. The relative humidity in the screen-house was more than that of the open-field because there was less exposure to direct sunlight. Lower temperature value was also recorded in the screen-house compared to the open field. These were responsible for the performance of the selected vegetables that was generally better in the screenhouse than open field. This was because screen-house created a modified microclimate in which radiation and wind movement were lowered but relative air humidity was higher than in the open field, resulting in reduction in evapo-transpiration.

Variations that were observed in the response of different vegetables to organic and inorganic fertilisers were due to the nature of the two types of fertilizer and the growing pattern of these vegetables. Addition of NPK fertiliser gave the highest plant height at 6 WAS especially for A. cruentus and C. argentea vegetables compared to compost both in the screen house and open field. Compost is known for slow rate of mineralization by releasing its nutrients slowly to the soil unlike NPK fertiliser. These nutrients were however, made available to the Solanum varieties (S. incanum, S. macrocarpon, and S. nigrum) being slowgrowing plants and their growth rates synchronized with the rate of nutrient release in compost at which time the NPK would have been leached out as at the time when $\mathrm{S}$. varieties were just coming up. This therefore explained the positive response of Solanum species to compost more than other vegetables. This coupled with the availability of essential nutrients in compost accounted for the better performance of Solanum vegetables in 
compost amended soils under both conditions of open field and screen-house. This was also in accordance with earlier reports that organic amended soil supplies twice the essential nutrients than inorganic fertilizer.

Generally, it was observed that the leaf area of the different vegetables increased under the screenhouse conditions compared to the open-field. This might be attributed to increase in the activities of metabolic enzymes under reduced temperature in the screen-house, the condition that will support the synthesis of proteins needed for structural buildup. High temperature induced by high light intensity has been implicated in the increase in evapotranspiration, leaf/canopy temperature and disruption of physiological processes. Addition of fertilizer, especially, compost reduced the effect of the temperature on the open-field grown vegetables better than NPK fertilizer due to the water retaining ability of organic fertilizer. Nutrient availability in sufficient amount has been reported to improve plant leaf area development. Furthermore, there was a significant increase in the growth parameters of S. nigrum, S. macrocarpon and $S$. incanum under the screen-house condition in combination with compost amendment due to reduction in water loss which in turn enhances chlorophyll formation, photosynthesis and biomass accumulation in the screenhouse more than the open field. In search for light, the solanum species grown in the screenhouse also had taller stems compared to those grown on the open field. The increase in plant height under shade has also been reported to be due to removal of the light induced inhibition of gibberrelic acid which is known to be responsible for stem elongation.

Light however, enhances leaf formation in the open field where higher number of leaves was recorded. The reason given for this was that under high light intensity, the increase in leaf transpiration rates could facilitate the efficient uptake of water and nutrient from the soil which inturn could have increased the rate of photosynthesis and leaf production. The Amaranthus species that out-performed other vegetables under the open field condition belongs to the plant species that make use of carbon four photosynthetic pathway and these plants have been reported to have high photosynthetic efficiency under high light intensity due to their high water use efficiency coupled with reduction in photorespiration process; a wasteful physiological process. Meanwhile, other vegetables that did not perform well under high light intensity belong to the carbon three plant species that follow Carbon three photosynthetic pathway. The physiological processes of these plant species are usually affected by high light intensity due to the increase in photorespiration and water loss. This probably was responsible for poor growth of these vegetables and low biomass accumulation under open field.

Low-light intensities in the screen-house also improved the chlorophyll pigments formation of the leaves compared to open field conditions. The Solanum varieties which are always rich in chlorophyll concentrations had more chlorophyll in the screen-house than the open-field. The increase in chlorophyll concentration could also be attributed to low temperature and water availability, all of which results in increase in physiological and biochemical processes. Chlorophyll production has been reported to decrease under high light intensity due to impairment in enzymatic activities as a result of increase in temperature. Besides, degradation of chlorophyll has also been reported under severe stress like drought and high light intensity (Arnao and Hernandez-Ruiz, 2009). The degradation might have been caused by increase in the production of reactive oxygen species under high light intensity/temperature (Siddiqi et al., 2009; Jalal et al., 2012). The increase in transpiration rate under high light intensity might have also reduced the available water for physiological processes like chlorophyll synthesis.

It has been reported that leafy vegetables have high moisture content ranging from $72.93 \%$ to $91.83 \%$ (Kwenin et al., 2011). George (2003) stated that moisture content makes an important contribution on the texture of the leaves and helps in maintaining the protoplasmic content of the cells. In this study, the significant difference observed may be due to the cultivation conditions that influenced the water level of vegetables (Florkowski et al., 2009). Screen-house conditions increased the biomass accumulation and leaf area development and, it also increased the moisture content of the tested vegetables more than those grown under the open field probably due to reduction in transpiration and ability to retain water in the protoplasm for a longer period of time. The ash content of any sample is also the measure of the mineral contents present in such sample. The result of the ash content revealed that fertilizer application and growing environment have significant effects on ash contents of the vegetables. With fertilizer, nutrients are made available and with the provision of shade in the screen-house there was efficient conversion of the absorbed nutrients to food which in turn results in high ash contents. Not only the ash content was enhanced, the crude protein production was also positively affected due to reduction in temperature and consequent increase in protein synthesis and enzymatic activities under optimum temperature. Meanwhile, leafy vegetables, though are good sources of protein and they help in building, and maintaining plant tissues, but depending on the species and type of vegetable, the ash and crude protein contents varied. The crude protein content of A. cruentus vegetable was the highest, while $S$. incanum vegetable showed the least crude protein content. The level of protein in the vegetables generally indicates that they are very important for human health and are good supplements for humans.

The differences in the micronutrient contents of the tested vegetables may be attributed to their differences in type of fertiliser, availability and absorption efficiencies. Nutrient concentrations in foods depend largely on the quality of soil in which the crops are grown. Soil fertility management practices were reported to affect zinc and iron concentrations in vegetables and there was a direct association between soil chemical properties and vegetable mineral concentrations (Amuri et al., 2017). Mexican sunflower compost is a good source of necessary nutrients which is an indicative that the materials are good sources of plant nutrients for maximum production of vegetables. This is in agreement with Atayese and Liasu (2001) that mexican sunflower compost contained arbuscular mycorrhizal fungi spore which enhanced absorption 
of nutrients from soil to biomass. Different plant varieties also have different root system and hence different efficiency in exploiting and taking up nutrients from the soil. Zinc content in C. argentea at $100 \mathrm{kgN} /$ ha was significantly higher than what was reported in other commonly grown vegetables (Kamga et al., 2013). There was no significant difference in the Zinc contents of the $\mathrm{S}$. varieties which may be attributed to the diversion of minerals towards plant development and possibly antioxidant production.

Under both conditions however, Mexican sunflower compost treated soils performed better than inorganic fertilizers and this could be attributed to the nutrient availability as earlier reported for compost (Qureshi, 1990, Adejumo et al., 2011). High level of nutrient has also been reported in Mexican sunflower and this contributed to its acceptability by soil fertility scientists as a good source of plant nutrients (Sacred Africa, 2007). Vegetables had the highest fresh and dry weight yield in response to compost application especially in the screen-house conditions which confirms the findings of Ganunga et al. (1998) and Adejumo (2010) who reported the effectiveness of Mexican sunflower in soil fertility improvement.

\section{CONCLUSION AND RECOMMENDATION}

This study showed that for the S. varieties, Mexican sunflower at $10 \mathrm{t} /$ ha performed well in all growth parameters especially under low irradiance. Leafy vegetables grown inside screenhouses, shades or low light intensities also performed excellently well than the ones grown under direct sunlight. It is therefore recommended that leafy vegetables should be grown under shade using Mexican sunflower compost at 10t/ha as this increased the growth and yield of the vegetables.

\section{REFERENCES}

Adejumo, S. A. (2010). Compost-Remediation of a heavy metal contaminated site and its effects on maize (Zea mays L.) growth and yield in Ibadan, Nigeria- Ph.D Thesis, Department of Crop Protection and Environmental Biology, University of Ibadan.

Adejumo, S. A., Togun A. O., Adediran J. A., \& Ogundiran M. B. (2011). Field Assessment of progressive remediation of soil contaminated with lead-acid battery waste in response to compost application. Pedologist, 54(3), $182-193$.

Agbogidi, O. M., \& Ofuoku, A. U. (2005). Response of sour sop (Annona muricata Linn.) to crude oil levels. Journal of Sustainable Tropical Agricultural Research. 16:98-102.

Akinfolarin, O. M., \& Gbarakoro S. L. (2016). Proximate analyses of Atama (Heinsia crinita) and Editan (Lasianthera africana). IOSR Journal of Applied Chemistry, 9(3), 76-79. https://doi.org/10.9790/57360903017679

Amuri, N., Mhoro, L., Mwasyika, T., \& Semu, E. (2017). Potential of Soil Fertility Management to Improve Essential Mineral Nutrient Concentrations in Vegetables in Dodoma and Kilombero, Tanzania. Journal of Agricultural Chemistry and Environment, 6, 105-132. https://doi.org/10.4236/jacen.2017.62007

Arnao, M. B., \& Hernández-Ruiz, J. (2009). Protective effect of melatonin against chlorophyll degradation during the senescence of barley leaves. Journal of Pineal Research, 46(1), 58-63. https://doi. org/10.1111/j.1600-079X.2008.00625.X

Assogba-Komlan, F., Anihouvi, P., Achigan-Dako, E., Sikirou, R., Boko, A., Adje, C., Ahle, V., Vodouhè, R., \& Assa, A. (2007). Pratiques culturaleset teneur en éléments antinutritionnels(nitrates pesticides) du S. macrocarpon au sud du Bénin. African Journal of Food and
Agriculture Nutrition and Development, 7(4), 1-21.

Atayase, M. O., \& Liasu, M. O. (2001). Arbuscular mycorrhizal fungi weeds and earthworm interactions in the restoration of soil fertility in the guinea savanna region of Nigeria. Moor Journal of Agricultural Research, 3, 104-109.

Barminas, J. T., Charles, M., \& Emmanuel, D. (1998). Mineral composition of non-conventional leafy vegetables. Plant Foods for Human Nutrition, 53(1), 29-36. https://doi.org/10.1023/a:1008084007189

Chinoy, N., Verma, R., \& Patel, K. (1983). Effect of calcium on sperm motility of cauda epididymis in vitro. Retrieved from www.ncbi.nlm.nih.gov/m/pubmed/6675388/

Dhellot, J. R., Matouba, E., Maloumbi, M. G., Nzikou, J. M., Ngoma, D. G. S., Linder, M., Desobry, S., \& Parmentier, M. (2006). Extraction, chemical composition and nutritional characterization of vegetable oils: Case of $A$. hybridus (Var 1 and 2) of Congo Brazzaville. African Journal of Biotechnology, 5(11), 1095-1101.

Emebu, P. U., \& Anyika, U. (2011). Proximate and composition of Kale (Brassica oleracea) grown in Delta State, Nigeria. Pakistan Journal of Nutrition, 10, 190-194.

Ferdous, M. G., \& Baten, M. A. (2011). Climatic Variables of 50 Years and their trends over Rajshahi and Rangpur Division. Journal of Environmental Science and Natural Resources, 4, 147-150.

Florkowski, J. W., Robert, L. S., Bernhard, B., \& Stanley, E.P. (2009). Postharvest handling: Asystems approach ( $2^{\text {nd }}$ Eds. $)$, Academic Press.

Ganunga, R., Yerokun, O., and Kumwenda, J. D. T. (1998) Tithonia diversifolia: an organic source of nitrogen and phosphorus for maize in Malawi. In: Soil fertility research for maize-based farming systems in Malawi and Zimbabwe. S. R. Waddington, H. K. Murwira, J. D. T. Kumwenda, D. Hikwa, \& F.Tagwira (Eds.), Soil Fertility Network, CIMMYT, Harare (Zimbabwe).

George, P. M. (2003). Encyclopedia of foods. Humane Press; Washington.

Halliwell, B., \& Gutteridge J. M. (1989). Free radicals in biology and medicine. Clarendon Press, Oxford.

Jalal, R. S., Bafeel, S. O., \& Moftah, A. E. (2012). Effect of salicylic acid on growth, photosynthetic pigments and essential oil components of Shara (Plectranthus tenuiflorus) plants grown under drought stress conditions. International Research Journal of Agricultural Science and Soil Science, 2(6), 252-260.

Jerzykiewicz, J. (2007). Alkaloidy roślin z rodziny psiankowatych (Solanaceae) [Alkaloids of Solanaceae (nightshade plants)]. Postepy Biochemii, 53(3), 280-286.

Kamga, R., Kouamé, C., Atangana, A., Chagomoka, T., Ndango, R. (2013). Nutritional Evaluation of Five African Indigenous Vegetables. Journal of Horticultural Research, 21(1), 99-106. https:// doi.org/10.2478/johr-2013-0014

Kennedy, G., Nantel, G., \& Shetty, P. (2003). The source of "hidden hunger": global dimensions of micronutrient deficiencies. Food Nutrition and Agriculture, 32, 8-16.

Kolawole, E. L., \& Sarah, O. A. (2009). Growth and Yield performance of $A$. cruentus influenced by planting density and poultry manure application. Notulae Botanicae Horti Agrobotanici Cluj-Napoca 37(2), 196-199. https://doi.org/10.15835/nbha3723458

Kwenin, W. K. J., Woli, M., \& Dzomeku, B. M. (2011). Assessing the nutritional value of some African indigenous green leafy vegetables in Ghana. Journal of Animal \& Plant Sciences, 10(2), 1300- 1305.

Makinde, E.A. (2007). Evaluation of organomineral fertiliser on growth, yield and quality of A.cruentus on two soil types in Lagos state, Nigeria. Ph.D thesis, Department of Agronomy University of Ibadan.

Martirosyan, D. M., Miroshnichenko, L. A., Kulakova, S. N., Pogojeva, A. V., \& Zoloedov, V. I. (2007). Amaranth oil application for coronary heart disease and hypertension. Lipids in Health and Disease, 6, 1. https:// doi.org/10.1186/1476-511X-6-1

Natural News. (2009) Zinc deficiency linked to prostate enlargement.

Qureshi, J. N. (1990). The cumulative effect of fertilisers, manure and crop residues on maize and bean yields and some soil chemical properties at Kabete. Second KARI Annual Scientific Conference, Nairobi, Kenya.

Roberts, M. F., \& Wink, M. (1998). Plenum: New York, NY, USA. pp. 11-44.

Sato, T., M., \& Engle, L. M. (2002). Evaluation of antioxidant activity of indigenous vegetables from South and Southeast Asia. In JIRCAS Research Highlights, 10-11. Ohwashi, Tsukuba, Ibaraki, Japan.

Scared Africa. (2007). Using of tithonia as an organic fertilizer, sustainable agriculture center for research and development in Africa. Bungoma Kenya.

Schippers, R. R. (2000). African indigenous vegetables. An overview of 
the cultivated species. Natural Resources Institute/ACPEU Technical Centre for Agricultural and Rural Cooperation, Chatham, United Kingdom.

Siddiqi, E. H., Ashraf, M., Hussain, M., \& Jamil, A. (2009). Assessment of intercultivar variation for salt tolerance in safflower (Carthamus tinctorius L.) using gas exchange characteristics as selection criteria. Pakistan Journal of Botany, 41, 2251-2559.

Smestad, A. (2014). The effect of light on plant growth. Retrieved from http://www.ehow.com/about 5251025 effect-light-plant-growth.html Sodipo, O. A., Abdulrahman, F. I., Sandabe, U. K., \& Wampana, B. (2012). Endocrine function with aqueous fruit extract of $S$. macrocarpum Linn. in albino ratschronically administered triton-X to induce hyperlipidemia. Journal of Pharmacy, 2(3), 464474.

Xiao, J. F., Liu, Z. G., Yu, X. G., Zhang, J. Y., \& Duan, A. W. (2000) Effects of different water application on lint yield and fiber quality of cotton under drip irrigation. Acta Gossypii Sinica, 12, 194-197. 